Vol. 18 (2009): 57-68.

\title{
Fertilizer value of urine in pumpkin (Cucurbita maxima L.) cultivation
}

\author{
Surendra K. Pradhan*, Susanna Pitkänen, Helvi Heinonen-Tanski \\ Department of Environmental Science, University of Eastern Finland, PO Box 1627, FI-70211 Kuopio, Finland \\ *e-mail: surendra.pradhan@uef.fi
}

\begin{abstract}
The fertilizer value of human urine was compared with mineral fertilizer in pumpkin (Cucurbita maxima) cultivation at a dose of $113 \mathrm{~kg} \mathrm{~N} \mathrm{ha}^{-1}$ with no-fertilization used as control. The growth of the vine was better in urine fertilized pumpkins than in mineral fertilized and non-fertilized pumpkins. Total fruit biomass was higher in mineral fertilized plants compared to urine fertilized and non-fertilized pumpkins. Urine fertilized pumpkins may have suffered from lower potassium or higher chloride, thus they produced fewer flowers and fruits. However, total fruit biomass and the number of fruits were slightly higher in urine fertilized plants than in their non-fertilized counterparts, i.e. $17.2 \mathrm{t} \mathrm{ha}^{-1}$ more pumpkin could be produced with urine fertilizer. The microbial hygiene quality as well as the contents of soluble sugars, protein and taste quality were similar in all treatments, but lower nitrate and higher chloride contents were recorded in urine fertilized pumpkins than other treatments. In conclusion, our study shows that the production rate of urine fertilized pumpkins was somewhat lower than mineral fertilized pumpkins but it was higher than non-fertilized pumpkins. The hygienic quality was equally good with all treatments.
\end{abstract}

Key-words: Glucose, Nitrogen, Recycle, Sanitation, Vegetables, Waste.

\section{Introduction}

Sanitation is an important Millennium goal (UN 2007) and the so called "eco-toilet" or urine separating toilet could represent a good solution to this problem. Even in Europe, there are 33.4 million rural people without sanitation services (Aertgeerts 2008). When such services are installed then the urine separating toilet systems may be a practical option. In human excreta, urine contains most of the nitrogen $(\mathrm{N})$ that is excreted, but there is also some phosphorus (P) and potassium (K) (Schouw et al. 2002); i.e. its fertilizer value or nutrient propor- 


\section{AGRICULTURAL AND FOOD SCIENCE}

Pradhan, S.K. Urine fertilization in pumpkin cultivation

tion corresponds to NPK 18:2:5 (Lindén 1997). In general, pure human urine contains very few enteric microorganisms (Heinonen-Tanski et al. 2007). The nutrient content in human urine is in the range of a good fertilizer for plants and this can represent a novel way of recycling of nutrients.

The urea and ammonium found in urine and in artificial fertilizers are chemically similar i.e. 90 $100 \%$ of urine $\mathrm{N}$ is either present as urea or as ammonium, thus they are readily available for plants as Kirchmann and Pettersson (1995) have verified in fertilizing experiments. The $\mathrm{P}$ and $\mathrm{K}$ contents in urine are also almost totally (95-100\%) inorganic, i.e. readily plant available (Lentner 1981, Kirchmann and Pettersson 1995). In scientific studies in Finland, urine has been successfully used to fertilize cucumber (Heinonen-Tanski et al. 2007) and cabbage (Pradhan et al. 2007). The growth and yields were as good as could be obtained with mineral fertilization. However, it is important to study the use of urine fertilizer with different crop plants because of their different nutrients requirements and the variation in the nutrient content in urine. In particular, the high amount of $\mathrm{Cl}^{-}$and the relatively low amount of $\mathrm{P}$ in urine might evoke different responses in different plants. Pumpkin was selected for this work because of its worldwide distribution and it is often cultivated near to homes and it is believed to have high nitrogen needs (Reiners 1997). The flowers and young shoots of the pumpkins are also edible and the ripened pumpkin can be preserved for a long time at room temperature. Pumpkin is a flowering vine plant so it is important to study the response of urine on its reproductive parts.

The main objectives of this study were to evaluate the use of urine fertilizer 1) on the growth and yield of pumpkin, 2) on the chemical and hygienic quality of the yield and 3) on the flavor characteristics of the fruit by comparing the effects of fertilization with urine and conventional, mineral fertilization on these properties. Our working hypothesis was that the yield, hygienic and chemical quality of urine fertilized pumpkin fruits would be similar to that of conventionally i.e. mineral fertilized, pumpkin fruits.

\section{Materials and methods}

\section{Plant materials and plantation}

Pumpkin (Cucurbita maxima L. Ver. cabaza) seeds (Hammenhögs) were sown in small pots in a greenhouse on 7th May 2007. The fully grown seedlings with similar vine lengths were planted outdoors in the research garden of University of Kuopio, $\left(62.9^{\circ} \mathrm{N}\right.$ and $\left.27.7^{\circ} \mathrm{E}\right)$ on 6th June 2007 . The total cultivation area was $80 \mathrm{~m}^{2}$, this being divided into 12 plots each of $3 \mathrm{~m}^{2}$ area with about $40 \mathrm{~cm}$ (total $32 \mathrm{~m}^{2}$ ) narrow protecting strips between the different treatment plots with no vegetation in these protective strips. The cultivated soil was clay loam and the soil characteristics in the upper $15 \mathrm{~cm}$ soil layer are shown in Table 1. The cultivated area had been used for cultivation of cabbage in 2006 and before that time it was a grass field. The experiment area was designed as a Latin square model for three different treatments i.e. no fertilizer, mineral fertilizer and urine fertilizer all with four replicates. One pumpkin plant was cultivated in each plot.

\section{Fertilizer treatments}

Urine fertilized and mineral fertilized plots were both treated with a dose of $113 \mathrm{~kg} \mathrm{~N} \mathrm{ha}^{-1}$ (Table 2). Urine fertilizer (low concentrated NPK 0.93-0.063-0.36 and high concentrated NPK 8.17-0.65-2.1) was arranged so that the applications were first $7.3 \mathrm{~L}$ plant $^{-1}$ with low concentrated urine on cultivation days 5 and 7 after planting, and then 0.84 L plant $^{-1}$ with high concentrated urine on days 13, 19 and 45. The urine was applied with a measuring beaker and sprinkled on the soil about $50 \mathrm{~cm}$ around the plants. The soil surface was tilled before and after application of urine fertilizer so that the liquid could be better absorbed.

Mineral fertilizer (Puutarhan Y-lannos 1, NPK 10-7-14 i.e. $7 \% \mathrm{NH}_{4}^{+}-\mathrm{N}$ and $3 \% \mathrm{NO}_{3}^{-}-\mathrm{N}$ ) which also contained $\mathrm{Mg} 2 \%$, S 9\%, B $0.15 \%$, Cu $0.1 \%$, Fe $0.1 \%$, Mn $0.7 \%$, Mo $0.01 \%$, Zn $0.1 \%$ and Se $0.001 \%$ was also applied on days $5,9,13,19$, and 
Vol. 18 (2009): 57-68.

Table 1. Nutrient contents in the soil of the field experiment before and after cultivation, geometrical mean values $\pm \mathrm{SD}$ $(\mathrm{N}=4)$.

\begin{tabular}{|c|c|c|c|c|}
\hline \multirow[b]{2}{*}{ Soil characteristics } & \multirow{2}{*}{$\begin{array}{l}\text { Before cultivation } \\
\text { and fertilization }\end{array}$} & \multicolumn{3}{|c|}{ After cultivation and fertilization } \\
\hline & & None & Mineral & Urine \\
\hline Total-N ( $\left.\mathrm{g} \mathrm{kg}^{-1} \mathrm{DW}\right)$ & 23.34 & ND & ND & ND \\
\hline $\mathrm{NO}_{3}^{-}-\mathrm{N}\left(\mathrm{mg} \mathrm{kg}^{-1} \mathrm{DW}\right)$ & $224.31 \pm 83.9$ & $2.92 \pm 1.02$ & $3.66 \pm 0.79$ & $3.23 \pm 1.76$ \\
\hline $\mathrm{NO}_{2}^{-}-\mathrm{N}\left(\mathrm{mg} \mathrm{kg}^{-1} \mathrm{DW}\right)$ & 0.07 & $0.15 \pm 0.2$ & $0.21 \pm 0.15$ & $0.12 \pm 0.04$ \\
\hline $\mathrm{Cl}^{-}\left(\mathrm{mg} \mathrm{kg}^{-1} \mathrm{DW}\right)$ & $14.04 \pm 3.0$ & $24.68 \pm 11.57$ & $21.64 \pm 3.07$ & $20.14 \pm 6.41$ \\
\hline Water holding capacity (\%) & 43 & ND & ND & ND \\
\hline $\mathrm{pH}$ & 7.11 & 6.72 & 6.65 & 6.81 \\
\hline
\end{tabular}

$\mathrm{SD}=$ Standard deviation, $\mathrm{DW}=$ Dry weight, $\mathrm{ND}=$ Not determined.

Table 2. Applied amount of fertilizers plant ${ }^{-1}$ during the entire cultivation time and this fertilization being applied to a $3 \mathrm{~m}^{2}$ cultivation area.

\begin{tabular}{lcc}
\hline Amount of nutrients applied plant ${ }^{-1}$ & Mineral fertilizer & $\begin{array}{c}\text { Urine fertilizer ( low concentrated urine }+ \\
\text { high concentrated urine) }\end{array}$ \\
\hline $\mathrm{Ng}$ & 34 & $34(13.58+20.43)$ \\
$\mathrm{Pg}$ & 23 & $2.41(0.91+1.5)$ \\
$\mathrm{Kg}$ & 47.6 & $10.5(5.25+5.25)$ \\
Total fertilizer applied & $340 \mathrm{~g}$ & $17.1(14.6+2.5) \mathrm{L}$ \\
\hline
\end{tabular}

45 with the applied dose being $68 \mathrm{~g} \mathrm{plant}^{-1}$ at each interval. Mineral fertilizer was applied about 50 $\mathrm{cm}$ around the plants and mixed by tilling the soil. Meanwhile, soil from no-fertilization treatment plots was also tilled to ensure uniform soil activity in all treatments.

\section{Urine collection and hygienic considerations}

The low concentrated urine was collected from several eco-toilets (where urine is collected separately from other excreta) in private homes from the Finnish Baltic Archipelago. The high concentrated urine was collected during the previous winter from several eco-toilets in private homes in the vicinity of Tampere, Finland. The collected urine was brought and stored at $+6{ }^{\circ} \mathrm{C}$ until use as fertilizer i.e. high concentrated urine was about $2-3$ months old and low concentrated urine about 1 year old. The stored urine was analyzed for its microbiological properties. The presence of Salmonella spp., fecal coliforms, clostridia, enterococci bacteria and coliphage virus was tested from the solution and sediment samples from the storage containers (Table 3). Salmonella spp. were determined by the ISO 6579 method (ISO 1993) including pre-enrichment, enrichment and confirmative plating on count on XLD and Rambach media. Fecal coliforms were determined by the SFS 4088 (SFS, 2001) standard plate count method on 
Pradhan, S.K. Urine fertilization in pumpkin cultivation

mFC agar and incubated at $44{ }^{\circ} \mathrm{C}$ for 24 hours. Enterococci were cultured on Slanetz-Bartley agar and incubated at $37^{\circ} \mathrm{C}$ for 48 hours (SFS 2000). The Finnish microbiological SFS-methods correspond to the methods of the American Public Health Association (2005). Clostridia were determined with sulphite-iron agar after heat treatment and anaerobic incubation at $37^{\circ} \mathrm{C}$ for 48 hours according to the SFS-EN-26461-2 plate count method (SFS 1993). After incubation, bacterial colonies were counted and microbial numbers calculated as CFU $\mathrm{ml}^{-1}$. Coliphages were determined by the ISO method (ISO 1998) with two Escherichia coli hosts i.e. ATCC 13706 and ATCC 15597 on THG agar by a double layer method (ISO 1998) and incubated at $37{ }^{\circ} \mathrm{C}$ for 24 hours; plaques were counted on the next day (Table 3 ). In the statistical evaluation of geometric means or log-transformed numbers half of the detection limit (i.e. $0.5 \mathrm{CFU}$ or PFU ml-1) was used when the count was 0 .

The nutrient contents of the urine; total-N, $\mathrm{NH}_{4}^{+}-\mathrm{N}, \mathrm{NO}_{3}^{-}-\mathrm{N}, \mathrm{NO}_{2}^{-}-\mathrm{N}$, total-P, $\mathrm{PO}_{4}^{-}-\mathrm{P}, \mathrm{K}$ were analyzed according to the SFS standard methods, which correspond to the APHA methods (APHA 2005). Total nitrogen was analyzed by the Kjeldahlmethod (ISO 1975). P and K were determined by colorimetric procedures with SFS 3026 and 8049 methods, respectively, ammonium by spectrophotometry (SFS 2005). These SFS methods correspond to the ISO methods for particular chemical analysis. $\mathrm{NO}_{3}^{-}, \mathrm{NO}_{2}^{-}$, and $\mathrm{Cl}^{-}$were analyzed by ion-chromatography (Dionex DX-120, AS40 Automated sampler, Dionex Corporation, USA).

Table 3. Main chemical parameters in the urine solution used ( $\mathrm{g} \mathrm{L}^{-1}$ urine except for $\left.\mathrm{pH}\right) . \log _{10}$ numbers $\pm \mathrm{SD}$ of Salmonella and some indicator microorganisms in urine solution and sediment (CFU ml-1 and PFU ml-1 for bacteria and coliphages, respectively) $(N=3)$. $\mathrm{ND}=$ not determined. $\mathrm{ldl}=$ less than detection limit, detection limit $=1 \mathrm{CFU} \mathrm{ml^{-1 }}$ and $1 \mathrm{PFU} \mathrm{ml}^{-1}$ except for Salmonella and fecal coliforms.

\begin{tabular}{|c|c|c|c|c|}
\hline Parameters & \multicolumn{2}{|c|}{ Low concentrated urine } & \multicolumn{2}{|c|}{ High concentrated urine } \\
\hline $\mathrm{pH}$ & \multicolumn{2}{|c|}{8.6} & \multicolumn{2}{|c|}{9.2} \\
\hline Chloride & \multicolumn{2}{|c|}{0.44} & \multicolumn{2}{|c|}{3.03} \\
\hline Total-P & \multicolumn{2}{|c|}{0.063} & \multicolumn{2}{|c|}{0.65} \\
\hline $\mathrm{PO}_{4}-\mathrm{P}$ & \multicolumn{2}{|c|}{ ND } & \multicolumn{2}{|c|}{0.62} \\
\hline Suspended P & \multicolumn{2}{|c|}{0.061} & \multicolumn{2}{|c|}{$\mathrm{ND}$} \\
\hline Total-N & \multicolumn{2}{|c|}{0.930} & \multicolumn{2}{|c|}{8.17} \\
\hline Ammonium- $\mathrm{N}$ & \multicolumn{2}{|c|}{0.940} & \multicolumn{2}{|c|}{8.57} \\
\hline Nitrate-N & \multicolumn{2}{|c|}{$<0.005$} & \multicolumn{2}{|c|}{0.01} \\
\hline Nitrite-N & \multicolumn{2}{|c|}{$<0.005$} & \multicolumn{2}{|c|}{$<0.01$} \\
\hline Potassium & \multicolumn{2}{|c|}{0.360} & \multicolumn{2}{|c|}{2.1} \\
\hline Microorganisms & Solution & Sediment & Solution & Sediment \\
\hline Salmonella spp. & ND & ND & none $25 \mathrm{ml}^{-1}$ & none $25 \mathrm{ml}^{-1}$ \\
\hline Fecal coliforms & none $40 \mathrm{ml}^{-1}$ & none $40 \mathrm{ml}^{-1}$ & none $30 \mathrm{ml}^{-1}$ & none $20 \mathrm{ml}^{-1}$ \\
\hline Enterococci & ldl & ldl & $0.8 \pm 0.7$ & $1.1 \pm 1.2$ \\
\hline Clostridia & 0.7 & 1 & ldl & ldl \\
\hline Coliphages host E. coli ATCC 13706 & 0.5 & 0.9 & $1.6 \pm 1.9$ & $1.9 \pm 2.2$ \\
\hline Coliphages host E. coli ATCC 15597 & ldl & ldl & ldl & ldl \\
\hline
\end{tabular}

Note: - Total-N showed slightly lower than $\mathrm{NH}_{4}^{+}-\mathrm{N}$, which might be due to small losses of $\mathrm{NH}_{4}^{+}-\mathrm{N}$ during the digestion process in Kjeldahl method. 
Vol. 18 (2009): 57-68.

\section{Climate and irrigation}

The monthly precipitation was 55, 113 and $56 \mathrm{~mm}$, and the average temperatures were 14.716 .7 and $16.6{ }^{\circ} \mathrm{C}$ in June, July and August as determined at the nearby Kuopio airport (Finnish Meteorological Institute 2007).

Pumpkin plants were irrigated for 2 hours every second day during the first month, for 3 hours every second day during the second and third month of the cultivation though there was no irrigation on rainy days. The irrigation was done by sprinkler irrigation and the wetting rate was $2 \mathrm{~mm} \mathrm{hr}^{-1}$ during the irrigation period. In this trial, the first frost came earlier so the cultivation could not be continued.

\section{Growth and harvest}

The vine length in the main vine and the area of the largest leaf of each plant were measured on every fifth to seventh day to determine the growth rate of the plants. Fully developed flowers were counted on every seventh day to determine the impact on the reproductive parts.

The pumpkins were harvested from day 74 up to day 92. The fruit biomass was recorded, and circumference and length of the fruits were measured.

\section{Microbial analyses}

Peeled pumpkin fruit, mesocarp, was used for the chemical and hygienic analyses (nutrient content and microbiological hygiene). A total of $20 \mathrm{~g}$ peeled pumpkins was mixed with $180 \mathrm{ml}$ of sterilized water and homogenized in grinder and this homogenized solution was used for the microbial analysis. Thus Salmonella spp., fecal coliforms, clostridia, enterococci and coliphages were determined with the same analysis as used for urine analysis with the detection limits being $10 \mathrm{CFU} \mathrm{g}^{-1}$ or $10 \mathrm{PFU} \mathrm{g}{ }^{-1}$, except for $1 \mathrm{CFU} 25 \mathrm{~g}^{-1}$ sample for Salmonella.

\section{Chemical analyses}

For analysis of $\mathrm{NO}_{3}^{-}, \mathrm{NO}_{2}^{-}$and $\mathrm{Cl}^{-}$, a representative sample of peeled and cut pumpkin from each experimental plot was dried at $60{ }^{\circ} \mathrm{C}$ for 4 days. Dry pumpkin material was milled, $0.5 \mathrm{~g}$ milled sample was mixed with $100 \mathrm{ml}$ ion free water $(18.2 \mathrm{M} \Omega)$ and heated at $50{ }^{\circ} \mathrm{C}$ for 30 minutes in a water bath, the solution was filtered and $5 \mathrm{ml}$ of the solution taken to a vial with a syringe filter. This extract sample was then frozen until analyzed. In the analyses of total-N and soluble sugar (sucrose, D-glucose, D-fructose), a parallel sample of peeled and cut pumpkins was freeze dried at $-50{ }^{\circ} \mathrm{C}$ for 4 days. $\mathrm{NO}_{3}^{-}, \mathrm{NO}_{2}{ }^{-}, \mathrm{Cl}^{-}$ and total-N were determined by the same methods as used for urine.

The freeze-dried samples were homogenized with a mortar, and $300 \pm 30 \mathrm{mg}$ (exact weight recorded for calculation) sample was weighed into a conical flask, $100 \mathrm{ml}$ of ion free water was added and stirred for 1 hour to make the solution. The mixture solution was filtered and subsequently the filtrate was treated with Carrez-I and Carrez-II solution to deproteinize it and it was filtered again to separate the precipitated protein. This solution was transferred into the cuvettes and monitored with enzymatic reactions at different time intervals for sucrose, D-glucose and D-fructose separately. After the enzymatic reactions, the samples were determined in a spectrophotometer at a wavelength of $340 \mathrm{~nm}$ and the absorbance recorded (Sekin 1978). The kit used for this assay was the enzymatic bio analysis/ food analysis system from R-biopharm, Germany.

\section{Flavor testing}

Triangle and ordinal taste testing of the fresh peeled chopped pumpkins from differently fertilized plots were conducted with a panel of 31 individuals; the ability of panel participants to recognize basic tastes (sweet, sour, salty and bitter) had been pre-tested according to the procedure recommended by Meilgaard et al. (1991). The panel consisted of 21 women and 10 men aged from 20 to 62 years, mainly university and polytechnic students and staff. The tasting ses- 


\section{AGRICULTURAL AND FOOD SCIENCE}

Pradhan, S.K. Urine fertilization in pumpkin cultivation

sion was organized in a test kitchen with the tasters being served three sliced pumpkin samples marked with blind code numbers in two triangle taste tests. In the first triangle test, three sliced fresh pumpkins were tasted, one or two samples from urine fertilized, with the other one or two being mineral fertilized and in the second test, they were supplied with sliced pumpkin samples from urine fertilized pumpkins with non-fertilized pumpkins in the same manner as in the first test. The tasters had to state which sample differed from the other two. In the ordinal test, the tasters were served with three sliced pumpkin samples from all different fertilizers with blind codes and they were asked to evaluate which sample they preferred. The tasters could drink water between the tests and taste the samples as many times as they wished without any time limitations. They could also comment on any possible differences in texture or color of the sliced pumpkin.

All these chemical, microbial and flavor analysis were conducted with peeled pumpkins, as mesocarp is the main part used of this variety of pumpkins. Similarly, for all these analysis, pumpkins were selected from the same harvesting day and similar size.

\section{Statistical analyses}

Basic data were organized in MS Excel, and general statistical parameter characteristics were calculated to characterize the overall feature of the data sets. Tests to ensure the normality of the raw and transformed data were performed prior to the other statistical analyses.

Fruit characteristics and results of microbial and chemical analysis were analyzed with SPSS 14.0 by one way variance analysis (ANOVA), and differences between averages assessed by Tukey's Post Hoc Test. The correlation between relevant characteristics was analyzed by Pearson correlation test (with 2-tailed test of significance). Kruskal Wallis Test and Mann-Whitney Test were also used to analyze the mean size of pumpkin fruits. The $p$ values below 0.05 were considered as statistically significant.

\section{Results}

\section{Urine quality}

The smell of the low concentrated urine was mild, whereas high concentrated urine had a strong ammonia odor. Very few microorganisms were detected in the hygienic analysis of the urine (Table 3 ).

\section{Plant growth}

The plants in all three treatments grew well. For assessment of the growth rate, the differences among treatments in vine length, number of branches on main vine and size of largest leaf were compared, and the results for the number of branches and leaf area were not significantly different characteristics (data not shown). Hence, only results for main vine length are shown to illustrate the growth rate (Fig. 1). The growth rate of mineral fertilized pumpkins was slightly better than the urine and non-fertilized pumpkin plots on day 23 of the trial, but the urine fertilized plants grew faster from day 44 and overtook the mineral fertilized treatment on about day 50 (Fig. 1), and by about day 65 even the nonfertilized vines were longer than the vines fertilized with mineral fertilizer. The growth rate of urine fertilized pumpkin was higher than for non-fertilized pumpkin during the whole experiment. However, the difference between treatments was statistically significant only on cultivation day $92(p=0.039)$

The growth of the fertilized pumpkins was more rapid, the flowering started on day 17 for the mineral fertilized pumpkins as compared to day 23 for urine and non-fertilized pumpkins. The numbers of flowers (Fig. 2, Table 4) and fruits (Table 4) were also comparatively lower in the urine fertilized and non-fertilized treatments (Fig. 2). Vine length and leaf area were strongly correlated $\left(r^{2}\right.$ $=0.956, p=0.0001)$ therefore only data for vine length is presented in Fig. 2.

The total fruit biomass of mineral fertilized pumpkins was considerably higher than for nonfertilized and urine fertilized pumpkins (Table 4). 
Vol. 18 (2009): 57-68.

Urine fertilized pumpkins had only a slight yield increase as compared to non-fertilized, and the increase was not statistically significant. The mean fruit size and circumference of urine fertilized pumpkins and mineral fertilized pumpkins were not statistically different, but pumpkin fruits from both fertilized treatments were statistically larger than non-fertilized pumpkin fruits. There was a tendency that urine fertilized pumpkins had the largest fruits, but the difference was not statistically significant (Table 4). On the other hand, the biomass of pumpkins and growth rate were positively correlated $\left(r^{2}=570-640, p=0.053-0.025\right)$ for cultivation days 30,37 and 44 .

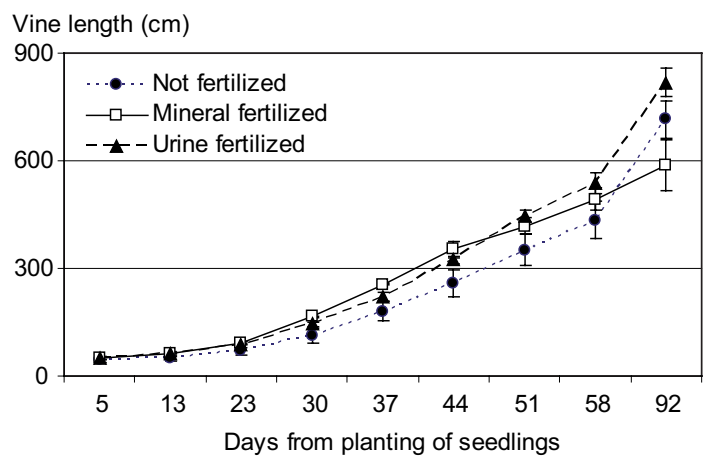

Fig. 1. Development of vine length of pumpkin plants in different fertilizer treatments. Bars show standard errors.

\section{Hygienic quality of the pumpkins}

Salmonella spp., fecal coliform, clostridia and coliphages were not found in any of the peeled pumpkins. A few enterococci were found in all treatments. The $\log _{10}$ numbers for enterococci were; non-fertilized pumpkins $0.8 \pm 1.3$, mineral fertilized $1.5 \pm 1.4$ and urine fertilized $1.1 \pm 0.2 \mathrm{CFU} \mathrm{g}^{-1}$. There were no significant differences between the groups.

The $\mathrm{NO}_{3}^{-}$contents were significantly higher in non-fertilized and mineral fertilized pumpkins than in the urine fertilized pumpkins (Table 5). For $\mathrm{NO}_{2}^{-}$, there were no significant differences between treatments. The $\mathrm{Cl}^{-}$contents were signifi-

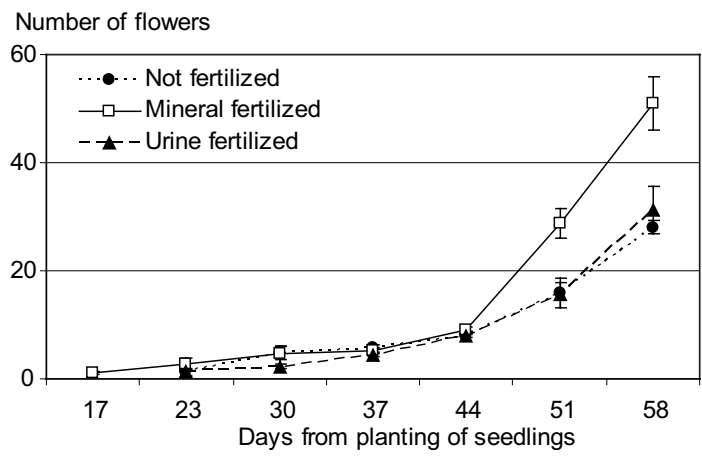

Fig. 2. Cumulative number of fully developed flowers in pumpkin plants with different fertilizer treatments during the growth period. Bars show standard errors.

Table 4. Total biomass $(\mathrm{kg})$, size $(\mathrm{kg})$, length $(\mathrm{cm})$, circumference $(\mathrm{cm})$ of the pumpkin fruits and number of flower and fruits in the pumpkins with different fertilizers, mean $\pm \operatorname{SD}(N=4) \cdot \chi^{2}=7.432$ for mean weight of pumpkins.

\begin{tabular}{|c|c|c|c|c|c|}
\hline \multirow[b]{2}{*}{ Parameters } & \multicolumn{3}{|c|}{ Fertilization treatments } & \multirow{2}{*}{$\begin{array}{c}f \\
\text { value }\end{array}$} & \multirow{2}{*}{$\begin{array}{c}p \\
\text { value }\end{array}$} \\
\hline & None & Mineral & Urine & & \\
\hline Total fruit biomass & $11.98 \pm 10.65^{\mathrm{a}}$ & $48.40 \pm 16.17^{b}$ & $17.14 \pm 8.51^{\mathrm{a}}$ & 10.421 & 0.005 \\
\hline $\begin{array}{l}\text { Mean weight of pumpkin } \\
\text { fruits }\end{array}$ & $2.22 \pm 0.59^{\mathrm{a}}$ & $6.05 \pm 0.24^{b}$ & $5.30 \pm 1.26^{\mathrm{b}}$ & 24.779 & 0.001 \\
\hline Length of pumpkin fruits & $30.38 \pm 5.77$ & $35.15 \pm 2.16$ & $43.94 \pm 10.16$ & 3.406 & 0.079 \\
\hline $\begin{array}{l}\text { Circumference of pumpkin } \\
\text { fruits }\end{array}$ & $48.28 \pm 13.41^{\mathrm{a}}$ & $71.73 \pm 2.62^{b}$ & $83.51 \pm 24.54^{b}$ & 11.698 & 0.003 \\
\hline Total number of fruits plant ${ }^{-1}$ & $3.00 \pm 1.15^{\mathrm{a}}$ & $7.8 \pm 2.36^{b}$ & $3.25 \pm 1.50^{\mathrm{a}}$ & 9.355 & 0.006 \\
\hline $\begin{array}{l}\text { Total number of flowers } \\
\text { plant }^{-1}\end{array}$ & $40.75 \pm 7.14^{\mathrm{a}}$ & $65 \pm 4.55^{\mathrm{b}}$ & $42 \pm 10.54^{\mathrm{a}}$ & 12.497 & 0.003 \\
\hline
\end{tabular}

The means indicated with the same letter within a row do not differ statistically significantly $(p<0.05)$. 
Pradhan, S.K. Urine fertilization in pumpkin cultivation

cantly higher in the urine fertilized treatment. $\mathrm{NO}_{3}{ }^{-}$ and $\mathrm{Cl}^{-}$contents in pumpkins were negatively, but not significantly correlated $\left(r^{2}=-0.497, p=0.10\right)$.

\section{Soluble sugar and protein}

There was no significant difference between treatments in the concentrations of soluble sugars (sucrose, D-glucose and D-fructose) or protein content. D-glucose was the predominant compound in all treatments, the sucrose and D-fructose contents were lower and similar in all treatments (Table 5).

\section{Flavor quality of the pumpkins}

In the taste assessment test, 15 out of the 31 panelists could taste a difference between the pumpkins fertilized with urine and those fertilized with mineral fertilizer, but this was not statistically significant (Roessler et al. 1978). However, 16/31 panelists could differentiate the urine fertilized pumpkin from the non-fertilized. In general, the panelists did not prefer any particular treatment i.e. nine preferred the non-fertilized, twelve preferred mineral fertilized and ten preferred urine fertilized pumpkin. Many panelists said that in their opinion there was really no difference in gustatory qualities.

\section{Discussion}

The total fruit biomass was highest in mineral fertilized pumpkins compared to the other treatments. This result was related to the number of flowers and fruits and one of the possible reasons could be abortion of flower due to salinity in urine fertilized plants (Botia et al. 2005). However, there was no salinity increase in urine fertilized plots after cultivation. The fruit sizes from mineral fertilized plots and urine fertilized plots were similar and both were clearly larger than the pumpkins from the non-fertilized plots. Large fruits with thick mesocarp flesh are more useful for food processing. However, 17.2 $\mathrm{t}$ ha $\mathrm{a}^{-1}$ more pumpkins can be produced with urine fertilizer compared to no-fertilization and the total fruit biomass of the non-fertilized plants could have

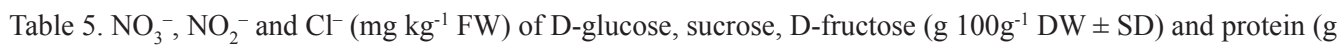
$100 \mathrm{~g}^{-1} \mathrm{FW} \pm \mathrm{SD}$ ) contents in edible portion of in pumpkin in the different fertilizer treatment groups geo-mean $\pm \mathrm{SD}$ $(N=4)$.

\begin{tabular}{|c|c|c|c|c|c|}
\hline \multirow[b]{2}{*}{ Nutrients fresh pumpkin } & \multicolumn{3}{|c|}{ Fertilization treatments } & \multirow{2}{*}{$\begin{array}{c}f \\
\text { value }\end{array}$} & \multirow{2}{*}{$\begin{array}{c}p \\
\text { value }\end{array}$} \\
\hline & None & Mineral & Urine & & \\
\hline $\mathrm{NO}_{3}^{-}$ & $693 \pm 250^{a}$ & $569 \pm 348^{\mathrm{ab}}$ & $168 \pm 98^{b}$ & 5.035 & 0.034 \\
\hline $\mathrm{NO}_{2}^{-}$ & $1.50 \pm 4.41$ & $0.61 \pm 0.35$ & $0.70 \pm 0.54$ & 1.121 & 0.368 \\
\hline $\mathrm{Cl}^{-}$ & $74 \pm 16^{\mathrm{a}}$ & $65 \pm 9^{a}$ & $123 \pm 24^{b}$ & 13.468 & 0.002 \\
\hline D-glucose & $15.34 \pm 1.09$ & $15.99 \pm 1.10$ & $16.33 \pm 0.71$ & & \\
\hline Sucrose & $1.71 \pm 1.45$ & $0.11 \pm 1.44$ & $1.74 \pm 2.01$ & & \\
\hline D-fructose & $1.38 \pm 0.50$ & $0.91 \pm 1.94$ & $0.90 \pm 1.69$ & & \\
\hline Protein & $0.44 \pm 0.07$ & $0.36 \pm 0.08$ & $0.40 \pm 0.08$ & 3.148 & 0.092 \\
\hline DW of mesocarp (\%) & $4.47 \pm 1.0$ & $4.05 \pm 0.3$ & $4.70 \pm 0.7$ & & \\
\hline
\end{tabular}

The means indicated with the same letter within a row do not differ statistically significantly $(p<0.05)$. FW $=$ Fresh weight. Protein was calculated by the total nitrogen multiply with 6.25 . 
Vol. 18 (2009): 57-68.

been even lower if the cultivation land had been of poorer quality such as sandy soil, soil after erosion or long time abandoned land.

Initial growth rate of pumpkin plants in mineral fertilized plots was higher than urine fertilized plots, but later the growth rate was better in urine fertilized plots as has been found in previous studies with cabbage and cucumber cultivation (Pradhan et al. 2007 and Heinonen-Tanski et al. 2007). One possible explanation for high initial growth in mineral fertilized pumpkins might be that it has an optimal $\mathrm{NO}_{3}{ }^{-}-\mathrm{N}$ content $\left(3 \% \mathrm{NO}_{3}{ }^{-} \mathrm{N}\right)$ and $\mathrm{NO}_{3}{ }^{-}-\mathrm{N}$ is the preferred uptake compound of $\mathrm{N}$ for Cucurbita pepo (Chance et al. 1999). On the other hand, some of the $\mathrm{N}$ might have been lost from urine fertilizer, especially from high concentrated urine (Singurindy et al. 2006). Here, we did not dilute the urine because we were interested to examine its output from very normal practice as water may not be readily available in many parts of the world. Another possible explanation for this difference would be that the urine fertilized soil might have a slower nitrification process possibly as a result of the high chloride content. This explanation would conform to the proposal of Moussa et al. (2006) who showed that increasing salinity lead to a reduction of nitrification. Although the initial growth rate of mineral fertilized pumpkins was better, their growth ceased midway through the trial, possibly because of nitrogen deficiency, whereas the urine fertilized pumpkins still continued to thrive, this is similar to the growth with cucumber (Heinonen-Tanski et al. 2007) and with cabbage (Pradhan et al. 2007). It may be because the nitrogen in urine fertilizer has a longer available time than the nitrogen in mineral fertilizer. Unfortunately the concentrations of residual ammonium and total-N in fertilized soil were not studied. Some chemical parameters were assayed but they were not significantly different in between treatments (Table 1). In addition, the result showed that the growth rate and the total yield biomass was positively correlated $\left(r^{2}=570-640, p\right.$ $=0.053-0.025)$ on cultivation days 30,37 and 44 .

Granular mineral fertilizer can remain undissolved lying in the upper layer of dry soil e.g. during the dry season, if there is insufficient irrigation. On the contrary, urine is a soluble liquid fertilizer which may mean that nitrogen is more rapidly available and effective even in the dry season. However, it may be best to apply urine fertilizer in the evening or to irrigate after use of urine or to till the soil before and after the urine application as a way to reduce the $\mathrm{N}$ loss from urine fertilizer.

It should be noted that the study was only based on equal $\mathrm{N}$ levels in each treatment. Hence, $\mathrm{P}$ and $\mathrm{K}$ contents were much lower with urine fertilization compared to mineral fertilization (Table 2). The numbers of flowers were lower in non-fertilized plots and urine fertilized plots than mineral fertilized plots (Fig. 2, Table 4), and there may be a relation between the lower $\mathrm{P}$ and $\mathrm{K}$ application and the lower number of fruits, especially since the vine growth did not differ greatly between the treatments until the main flowering time. This may be traced to the lack of $\mathrm{P}$ or/and $\mathrm{K}$ meaning that the plants might take up $\mathrm{Na}^{+}$instead of $\mathrm{K}^{+}$as proposed by Kaya et al. (2007) in tomato plants. This result is supported by the findings that lower $\mathrm{K}$ uptake has been shown to reduce the number of flowers and fruits of almond (Prunus dulcis) (Reidel et al. 2004) or reproductive growth in cotton (Gossypium hirsutum L) (Read et al. 2006). Although the numbers of male and female flowers were not counted separately, the lower number of fruits in urine and non-fertilized plants points to a lower number of female flowers and this may be due to lower P or/ and $\mathrm{K}$ contents. This explanation is supported from the results of Grazia et al. (2003) who reported that the lower $\mathrm{K}$ could reduce the number of female flower in summer squash (Cucurbita maxima). Our study showed a lower number of fruits compared to the total number of flowers. This may be due to the fact that in pumpkins the male to female flower ratio is $<10: 1$ due to high/excessive fruit setting (Nayar and More 1998). In order to increase the $P$ and $\mathrm{K}$ availability, and thereby possibly the number of fruits, urine fertilized crops should also be supplied with other fertilizers e.g. meat and bone meal which is rich in $P$, or ash which is rich in $P$ and $K$.

Very few microorganisms were detected in the urine and they were present at a similar level as reported by Schönning (2001) and Heinonen-Tanski et al. (2007). The few pathogens in urine fertilizer actually applied into soil may pose a very low 


\section{AGRICULTURAL AND FOOD SCIENCE}

Pradhan, S.K. Urine fertilization in pumpkin cultivation

risk for agricultural consumer products compared to many other contamination sources around the field. This study showed that the hygienic quality of urine fertilized pumpkins did not differ between the treatments. All fertilized pumpkins contained a few enterococci possibly as a result of contamination by birds, insects etc. Nevertheless, urine fertilizer needs to be used with care to reduce any possible risks; it should never be applied directly to any parts of the plants, since in addition to possible microbial contamination, high concentrated urine can physically damage many plants. A protective period of some 25 days before harvesting is recommended (Jönsson et al. 2004).

The residual $\mathrm{NO}_{3}^{-}-\mathrm{N}, \mathrm{NO}_{2}^{-}-\mathrm{N}$, and $\mathrm{Cl}^{-}$contents in the soil were similar after all fertilizer treatments (Table 1). Surprisingly, the residual chloride content in soil from urine fertilized plots was similar to the plots receiving the other fertilizer treatments. This is possibly due to the high water solubility of chloride. The smaller number of fruits of the pumpkins in urine fertilized plots could be also attributable to the high chloride contents in the urine fertilizer (the salinity in the high concentrated urine was $47.2 \mathrm{mS} \mathrm{cm}^{-1}$ ), which could reduce the numbers of flowers, flower fertility and seed viability as presented by Labidi et al. (2004) with $35 \mathrm{mM}$ $\mathrm{NaCl}$ solution and Botia et al. (2005) with $6.1 \mathrm{dS}$ $\mathrm{m}^{-1}$ salinity for irrigation water.

In this study, urine fertilization did not change the contents of soluble glucose. The level of Dglucose was higher than sucrose and D-fructose with all treatments which is a similar trend to that presented by Kurz et al. (2008). The protein content in our pumpkins was lower compared to the values presented by Bognar (2006) i.e. $1.7{\mathrm{~g} 100 \mathrm{~g}^{-1} \mathrm{FW}}$

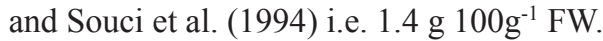

There were similar levels of $\mathrm{NO}_{3}^{-}$in mineral fertilized and non-fertilized pumpkins and those values are in agreement with the $\mathrm{NO}_{3}^{-}$concentrations (55-639 $\mathrm{mg} \mathrm{kg}^{-1}$ ) reported in fresh pumpkins from different countries by Thomson (2004). The $\mathrm{NO}_{3}^{-}$content in urine fertilized pumpkins was lower than in non-fertilized pumpkins. All pumpkin fruits were evaluated as tasting good, which may be due to their similar soluble sugar and other nutrients contents. Although the chloride content was higher in urine fertilized pumpkins than in the others this does not seem to be appreciable in the taste assessment.

In conclusions, this study supports one part of our working hypothesis and it demonstrated that the chemical and microbial quality of pumpkins cultivated with human urine fertilizer is as good as that achieved with traditional treatments. This study did not substantiate a second study hypothesis i.e. it seemed that there were lower pumpkin yields in urine fertilized plots compared to mineral fertilized plots, perhaps attributable to either the lower $\mathrm{K}$ or the higher $\mathrm{Cl}^{-}$contents present in urine fertilizer. Although, the total biomass was lower in urine fertilized groups compared to mineral fertilized groups but the productions can be $17.2 \mathrm{t} \mathrm{ha}^{-1}$ higher than can be achieved with no fertilization. However, this can be rectified by artificially elevating the $\mathrm{P}$ and $\mathrm{K}$ contents in urine with supplements as recommended for pumpkins cultivation. The effect of high $\mathrm{Cl}^{-}$contents in the urine on different plants and soil ecology needs to be studied further.

Acknowledgements: We would like to thank Professor Jarmo K. Holopainen for his valuable advice, Finnish Cultural Foundation for financial support and Dr. Ewen McDonald for English language correction.

\section{References}

Aertgeerts, R. 2008. Europe's success with water and health: a policy chronology. Water 21 April 2008: 45-48. American Public Health Association (APHA). 2005. Standard methods for the examination of water and wastewater. 21st Edition. Washington DC.

Bognar, A. 2006. Nutritive value of some varieties of pumpkin and winter squash grown in Germany. ErnährungsUmscha, 53: $305 \mathrm{p}$.

Botía, P., Carvajal, M., Cerdá, A. d Martinez, V. 2005. Yield and fruit quality of two melon cultivars irrigated with saline water at different stages of development, European Journal of Agronom, 23: 243-253.

Chance, W.O., Somda, Z.C. \& Mills, H.A. 1999. Effect of nitrogen form during the flowering period on zucchini squash growth and nutrient element uptake. Journal of Plants Nutritio, 22: 597-607.

Finnish meteorological institute. 2007. Home pages. IImatieteen laitos, meteorologiska institutet. Updated daily. Available on the internet: http://www.fmi.fi/il/index.html Grazia, J.D., Tittonell, P., Perniola, O.S., Ariel Caruso, A. \& 
Vol. 18 (2009): 57-68.

Chiesa, Y.A. 2003. Summer squash (Cucurbita maxima var. zapallito (Carr.) Millán) earliness and yield as affected by the nitrogen:potassium ratio. Agricultura Técnica (Chile), 64: 428-435. Available on the internet: https:// tspace.library.utoronto.ca/handle/1807/5096.

Heinonen-Tanski, H., Sjöblom, A., Fabritius, H. \& Karinen, P. 2007. Pure human urine is a good fertilizer for cucumbers. Bioresource Technolog, 98: 214-217.

ISO 1871. 1975. Agricultural food products - General directions for the determination of nitrogen by the Kjeldahl method.

ISO 6579,1993 . General guidance on methods for the detection of Salmonella.

ISO/DIS, 10705-2.2. 1998. Water quality-Detection and enumeration of bacteriophages- Part: 2, Enumeration of somatic coliphages.

Jönsson, H., Richert Stintzing, R., Vinnerås, B. \& Salomon, E. 2004. Guidelines on the use of urine and feces in crop production. EcoSanRes publication. Stockholm Environmental Institution (SEI). 2. 18 p.

Kaya, C., Tuna, A.L., Ashraf, M., Altunlu, H., Yokas, I. , Yagmur, B., 2007. The effects of calcium sulphate on growth, membrane stability and nutrient uptake of tomato plants grown under salt stress. Environmental and Experimental Botan, 59: 173-178.

Kirchmann, H. \& Pettersson, S. 1995. Human urine chemical composition and fertilizer use efficiency. Fertilizer Researc, 40: 149-154.

Kurz, C., Carle, R. \& Schieber, A. 2008. Characterization of cell wall polysaccharide profiles of apricots (Prunus armeniaca L.), peaches (Prunus persica L.), and pumpkins (Cucurbita sp.) for the evaluation of fruit product authenticity. Food Chemistr, 106: 421-430.

Labidi, N., Lachaal, M., Soltani, A., Grignon, C. \& Hajji, M. 2004. Variability of the effects of salinity on reproductive capacity of Arabidopsis thaliana. Journal of Plant Nutritio, 27: 1561-1573.

Lentner, C.G. 1981. Scientific tables. Units of measurement, body fluids, composition of the body, nutrition. 8th ed. Med. Education Div., Ciba-Geigy.

Lindén, B. 1997. Human urine as a nitrogen fertilizer applied during crop growth to winter wheat and oats in organic farming. Department of Agricultural Research. Skara, Serie-B, Crops and Soils Report 1. Sweden.

Meilgaard, M., Civille, G.V. \& Carr, B.C. 1991. Sensory evaluation techniques. 3rd edition CRC Press book. 61-68 p.

Moussa, M.S., Fuentes, O.G., Lubberding, H.J., Hooijmans, C.M., Van Loosdrecht, M.C.M. \& Gijzen, H.J. 2006. Nitrification activities in full-scale treatment plants with varying salt loads. Environmental Technolog, 27: 635-643.

Nayar N.M. , More, T.A., 1998. Cucurbits. Science Publishers, Inc., Enfield, New Hampshire, USA. 340 p.

Pradhan, S.K., Nerg, A-M., Sjöblom, A., Holopainen, J.K. \& Heinonen-Tanski, H. 2007. Use of human urine fertilizer in cultivation of cabbage (Brassica oleracea) - impacts on chemical, microbial and flavor quality. Journal of Agriculture and Food chemistr, 55: 8657-8662.

Read, J.J, Reddy, K.R. \& Jenkins, J.N. 2006. Yield and fi- ber quality of Upland cotton as influenced by nitrogen and potassium nutrition. European Journal of Agronom, 24: 282-290.

Reidel, E.J., Brown, P.H., Duncan, R.A., Heerema, R.J. \& Weinbaum, S.A. 2004. Sensitivity of yield determinants to potassium deficiency in 'Nonpareil' almond (Prunus dulcis (Mill.) DA Webb). Journal of Horticultural Science and Biotechnolog, 79: 906-910.

Reiners, S., Riggs, D.I.M., 1997. Improving yields of pumpkins through spacing, fertilizer, and irrigation. Published by The South Central New York Agriculture Team, Cornell University, Ithaca, NY. Updated on April 2009. Available on the internet: http://www.hort.uconn.edu/ipm/veg/ htms/maxpumprod.htm.

Roessler, E.B., Pangborn, R.M., Sidel, J.L. \& Stone, H. 1978. Expanded statistical tables for estimating significance in paired-preference, paired-difference, duo-trio and triangle test. Journal of Food Scienc, 43: 940-947.

Schönning, C. 2001. Hygienic aspects on the reuse of source-separated human urine. Paper prepared for NJF Seminar no. 327, Copenhagen. August 20-21.

Schouw, N.L., Danteravanich, S., Mosbaeck, H. \& Tjell, J.C. 2002. Composition of human excreta, a case study from Southern Thailand. Science of Total Environmen, 286: 155-166.

Sekin, S. 1978. Enzymatic determination of Glucose, Sucrose and Fructose in tobacco. Tobacco Scienc. 23: 7577 an; Tobacco Int, 181: 27-29.

SFS 4088, 2001. Membrane filter technique for the enumeration of thermotolerant (fecal) coliform bacteria in water. Finnish Standard Association, Helsinki, Finland. 4 p.

SFS-EN, 26461-2., 1993. Water quality. Detection and enumeration of the spores of sulfite-reducing anaerobes (clostridia). Part 2: Method by membrane filtration. Finnish Standard Association, Helsinki, Finland.

SFS-EN, ISO 7899-2., 2000. Water quality-Detection and enumeration of intestinal enterococci - Part 2: Membrane filtration method.

SFS-EN, ISO 11732: En., 2005. Water quality. Determination of ammonium nitrogen. Method by flow analysis (CFA and FIA) and spectrometric detection.

Singurindy, O., Richards, B.., Molodovskaya, M. \&, Steenhuis. T.S., 2006. Nitrous Oxide and Ammonia Emissions from Urine-Treated Soils: Texture Effec. Vadose Zone Journal, 5: 1236-1245.

Souci, S.W., Fachman, W. \& Kraut, H. 1994. Food Composition and Nutrition Tables. Fifth revised and completed edition. Scientific Publishers, Stuttgart, Medpharm. 896 p.

Thomson B. 2004. Nitrates and Nitrites Dietary Exposure and Risk Assessment. Institute of Environmental Science \& Research Limited New Zealand. Client report. FW 0392. Updated on June 2004. Available on the internet: http://www.nzfsa.govt.nz/consumers/food-safety-topics/chemicals-in-food/residues-in-food/consumerresearch/nitrite-nitrate-reportdf.

United Nations, (UN). 2007. Home pages. Updated on 2007. Available on the internet: www.un.org/millenniumgoals/ pdf/mdg2007.pdf 
